\title{
FCGR3A Gene
}

National Cancer Institute

\section{Source}

National Cancer Institute. FCGR3A Gene. NCI Thesaurus. Code C38558.

This gene plays a role in the mediation of antibody-dependent cytotoxicity and phagocytosis. 